\title{
DESVELANDO PLATÃO E ARISTÓTELES NO PENSAMENTO DE DWORKIN
}

\author{
FINDING OUT PLATO AND ARISTOTLE AT DWORKIN'S THOUGHT \\ ABSTRACT
}

\section{Ibraim José das Mercês Rocha}

Doutor e Mestre em Direito pela Universidade Federal do Pará (UFPA); Procurador Geral do Estado do Pará (PGE-PA).

Email: ibraimjrocha@gmail.com

Recebido em: 18/09/2018

Aprovado em: 16/03/2019

\begin{abstract}
RESUMO: O texto apresenta uma leitura que encontra pontos de encontro entre a obra de Ronald Dworkin e a obra de Platão e Aristóteles. Permitindo uma melhor leitura de Dworkin como um caminho para a efetividade dos Direitos Fundamentais, mediante uma prática interpretativa mais consistente, segundo um caminhar filosófico-jurídico, para a plena realização dos Direitos Humanos, Isto permite: 1- Construir o conteúdo substancial para além da leitura do texto constitucional, reconhecendo-se o Direito como a prática interpretativa mais competente para trazer objetividade as escolhas éticas da humanidade; 2- Adotar uma atitude filosófica frente aos conflitos normativos, identificando os princípios jurídicos que permitem encontrar a verdade, na formulação da resposta certa, afastando toda a forma de ceticismo;3- Construir um método de análise interpretativa comprometido com os valores éticos da comunidade personificada no Estado, para realizar os princípios adotados pela comunidade, como recurso para explicitar a coerência do todo, segundo o ideal de justiça da comunidade. 4 - Enfatizar a função do Poder Judiciário, exige que se indique os critérios racionais que limitam a discricionariedade judicial, e que se legitima quando protege os direitos fundamentais da comunidade, segundo um modelo de justiça distributiva.
\end{abstract}

Palavras-chave: Dworkin. Direitos Humanos; Interpretação Construtiva; Platão; Aristóteles.

ABSTRACT: This paper presents an interpreation that find conexions between Ronald Dworkin's
thougts with Plato and Aristotle 'thoughts. Allowing a better understandig of Dworkin as a path to
the effectiveness of Human rights, showing a more consistent interpretive practice, according a
philosophical-juridical path, helding a full realization of Human Rights, this permit: 1- To construct
substantial content of human righsts beyond reading of the constitutional text, recognizing Law as
the most competent interpretive practice to bring objectivity to the ethical choices of humanity; 2 .
To adopt a philosophical attitude towards normative conflicts, Identifying the law principles that
allow to find the truth, in the formulation of the right answer, removing all the form of skepticism;
3. To construct a method of interpretative analysis committed to the ethical values of the personified 
community represented by the State, to construct the principles adopted by the community, as a resource to make explicit the coherence of the whole, according an ideal of community justice. 4 Emphatizing the role of the Judiciary, it requires a rational path that limit judicial discretion, it has been legitimated when it protects the comunity'human rights, according a model of distributive justice.

Key-Words: Dworkin; Human Rights; Constructive Interpreation; Plato; Aristotle.

SUMÁRIO: Introdução; 1 Superação da Maldição do Tot; 2 Atitude Filosófica e Interpretação Construtiva - Identidade de Objetivos; 3 Processo Interpretativo de Construção da Unidade e a Figura do Juiz Hércules; 4 Racionalidade e Limites da Discricionariedade Judicial; 5 Justiça Distributiva e Promoção da Igualdade; Conclusão; Referências.

\section{INTRODUÇÃO}

Desperto para o objetivo da filosofia, Benedito Nunes ao perquirir sobre o advento da superação da filosofia, situa a diversidade dos produtos da cultura humana, onde inclui o Direito, como manifestações do caminhar do Espírito que nela se realiza, portanto o retorno à filosofia é que permitirá chegar ao seio do absoluto, da plenitude humana ${ }^{1}$.

O Objetivo deste texto, é seguindo estas pegadas, revelar as conexões de Dworkin com Platão e também com Aristóteles, encontrando o caminho que os une, o que facilita e aperfeiçoa a leitura da obra Dworkin, com ganhos para a prática e compreensão do Direito. Isto permite reconhecer o Direito como uma forma de filosofar, cuja prática interpretativa serve de instrumento para efetividade à proteção dos direitos fundamentais.

\section{SUPERAÇÃO DA MALDIÇÃO DO TOT}

Relata Platão, no Fedro, o mito segundo o qual havia nos arredores de Náucratis, no Egito, uma velha divindade que era conhecida pelo nome de Tot, e que foi a primeira a descobrir os números e o cálculo, a geometria e a astronomia, o jogo do gamão e dos dados, e também os caracteres da escrita. Nesse tempo, Tamus reinava em todo o Egito, e foi procurado por Tot, que lhe apresentou suas artes, com a sugestão de serem ensinadas aos egípcios. $\mathrm{O}$ rei, então, perguntou para que serviam todas elas e conforme Tot as explicava, ele as criticava ou elogiava. O rei Tamus fez observações em favor e contra cada uma das artes. Porém, quando chegou aos caracteres da escrita, disse Tot que apresentava uma disciplina capaz de deixar os egípcios mais sábios e com melhor memória, descobrindo o remédio para o esquecimento e a ignorância. Ao terminar de falar o Rei lhe asseverou:

Engenhosíssimo Tot, uma coisa é inventar as artes, e outra, muito diferente, discorrer sobre a utilidade ou desvantagem para quem delas tiver de fazer uso. Tal é o teu caso, como pai da escritura: pela afeição que lhe dedicas, atribui-lhes ação exatamente oposta à que lhe é própria, pois é bastante idônea para levar o esquecimento à alma de quem aprende, pelo fato de não lhe obrigar ao exercício da memória. Confiantes na escrita serão

\footnotetext{
${ }^{1}$ NUNES, Benedito. A superação da Filosofia In O Dorso do Tigre. São Paulo: Ed 34, 2009.
} 


\begin{abstract}
por meios externos, com a ajuda de caracteres estranhos, não no seu próprio íntimo e graças a eles mesmos que passarão a despertar suas reminiscências. Não descobriste o remédio para a memória, mas apenas para a lembrança. O que ofereces aos que estudam é simples aparência do saber, não a própria realidade. Depois de ouvirem um mundo de coisas, sem nada terem aprendido, considerar-se-ão ultrassábios, quando, na grande maioria, não passarão de ignorantões, pseudossábios, simplesmente, não sábios de verdade. (PLATÃO, Fedro, $274 \mathrm{E}-275$ B) ${ }^{2}$
\end{abstract}

Para o Direito cumprir o seu papel deve se afastar a maldição de Tot da interpretação dos direitos fundamentais, construindo o seu conteúdo substancial para além da leitura do texto constitucional, destacando o papel do intérprete de revelar o texto escrito, que sem ele nada diz, que é mudo e outra forma não encontra para exprimir os propósitos e valores da comunidade. Isso tanto mais é adequado numa era em que se pensa que os milhões de arquivos informatizados, disponíveis na internet, revelam a grande sapiência da sociedade, quando pode revelar exatamente o contrário, quando se deixa de indagar a que valores morais e políticos essas informações estão a serviço. Por isso, a interpretação jurídica, como elemento característico da Integridade do Direito, não pode considerar suficiente a existência do texto escrito para revelar o melhor propósito da comunidade.

O mito de Tot deixa claro que não se pode deixar fascinar pela linguagem e tomar as palavras como se fossem objetos vivos e com vontade própria, mas precisa do ser humano que as interpreta para que efetivamente tenha algum significado e que sozinhas não possuem nenhuma utilidade, como é exposto o argumento de Sócrates no $\mathrm{Fedro}^{3}$. Logo, se pode perceber, que o mito de Tot está presente no pensamento de Dworkin, quando afirma que o Direito é uma prática interpretativa, e que sem a qual não é possível se compreender o que é o Direito.

\title{
2 ATITUDE FILOSÓFICA E INTERPRETAÇÃO CONSTRUTIVA - IDENTIDADE DE OBJETIVOS
}

Desde o início da moderna filosofia, apesar de divergirem sobre o caminho, Platão e Aristóteles criaram métodos, pelos quais buscavam as respostas às questões fundamentais da humanidade, e, ainda que dissentes sobre a forma de perguntar, é possível identificar neles o elo comum de reconhecer que somente o ser humano, por ser capaz de formular princípios, poderia encontrar a verdade, ainda que por divergência de método. Um buscava a realidade do ser como reflexo das ideias; outro a partir do ser é que pretendia alcançá-las. Platão e Aristóteles, como verdadeiros filósofos, não sustentavam o ceticismo diante da possibilidade da humanidade alcançar a verdade, poderiam divergir quanto ao método, mas estavam firmes em seu propósito de, por meio das perguntas corretamente formuladas, obter respostas fundadas em princípios e por isso verdadeiras.

No livro I, capítulo VII, da Metafísica, após, nos antecedentes, ter realizado um resgate das teorias sobre a origem do ser desde os pré-socráticos e anunciando a crítica da teoria das ideias de Platão, Aristóteles apresenta a assertiva de que, embora ninguém tenha atingido a quididade e a substância com clareza, reconhece que "mais perto dela se aproximam os que admitem as ideias"

\footnotetext{
${ }^{2}$ PLATÃO. Fedro. Texto grego John Burnet. Tradução Carlos Alberto Nunes. 3. ed. Belém: Edufpa, 2011b. p. 183.

${ }^{3}$ PLATÃO, Fedro, 275 D - E)PLATÃO. Fedro. Texto grego John Burnet. Tradução Carlos Alberto Nunes. 3. ed. Belém: Edufpa, 2011b. p. 185.

${ }^{4}$ ARISTÓTELES. Metafísica. Tradução Vinzenzo Cocco e notas de Joaquim de Carvalho. São Paulo: Abril Cutural, 1979. Livro II. p. 26. (Coleção os Pensadores).
} 
e conclui reconhecendo que somente por princípios é possível alcançar a verdade afirmando que "evidente que os princípios devem ser estudados, ou todos assim, ou em qualquer uma destas maneiras".

Fundamental esse reconhecimento, que revela a unidade do pensamento platônico e aristotélico sobre a possibilidade de êxito do acesso ao conhecimento pela razão humana mediante a formulação de princípios, que é tarefa permanente do conjunto da humanidade ${ }^{6}$. Ante a grandeza dos seus pensamentos, até hoje se costuma voltar à mesma questão, em que se confunde o método com o objetivo, sendo eles claramente divergentes quanto ao caminhar. Esta distinção não parece fundamental, pois estes maiores pensadores da humanidade já haviam reconhecido que o essencial é a construção de princípios como resultado do uso da razão na compreensão do objeto, independente do tipo de objeto estudado, o que evidentemente força mudanças no método da abordagem. Consciente dessa armadilha a que o raciocínio lógico pode levar, já alertara Aristóteles que: "É por isso que importa saber como cada coisa se deve aceitar, pois é absurdo procurar ao mesmo tempo a ciência e o método da ciência: nenhum deles, pois é fácil de aprender" (Metafísica, Livro II, capítulo II, 4) ${ }^{7}$

A lição a que se pode chegar é que apesar das severas limitações, o conjunto do pensamento humano pode, passo a passo, superar os limites do conhecimento, entretanto, o essencial para obtenção do conhecimento da verdade não é testar o método, mas o princípio obtido pela razão. Assim, se o princípio é colocado como verdade a partir do método, pode-se afirmar que isso se constitui em grave erro para a correção do pensamento. Dessa forma, não há prova superior de um princípio ou de uma ciência em razão do método que utiliza. Um princípio pode ser testado em sua correção apenas em nível de argumentação, pois o fundamental não é o caminho, mas o objetivo do caminho, qual seja, a formação de juízos verdadeiros por meio de princípios ${ }^{8}$. Dwokin adota este caminho de princípios e, mesmo sem que declare, é possível encontrar elementos de uma teoria dos direitos fundamentais na sua obra, quando se observa que os critérios interpretativos que utiliza objetivam a construção do valor Justiça a partir de princípios constitucionais. A sua obra é uma

\footnotetext{
${ }^{5}$ ARISTÓTELES. Metafísica. Tradução Vinzenzo Cocco e notas de Joaquim de Carvalho. São Paulo: Abril Cutural, 1979. Livro II. p. 26. (Coleção os Pensadores).

${ }^{6}$ (Metafisica, Livro II, Cap. I, 1)"ARISTÓTELES. Metafísica. Tradução Vinzenzo Cocco e notas de Joaquim de Carvalho. São Paulo: Abril Cultural, 1979. Livro II. p. 39. (Coleção os Pensadores).

${ }^{7}$ ARISTÓTELES. Metafísica. Tradução Vinzenzo Cocco e notas de Joaquim de Carvalho. São Paulo: Abril Cultural, 1979. Livro II. p. 43. (Coleção os Pensadores)

${ }^{8}$ No opúsculo A Ideia do Bem entre Platão e Aristóteles, Hans-Georg Gadamer faz um interessante exercício filosófico de construção de um diálogo entre os princípios da filosofia platônica e aristotélica, ainda que sublinhando a sua distinção, mas destaca que no campo da filosofia prática (moral) há evidente convergência entre estes pensadores, como detalha especialmente no capítulo V do livro, e, por isso mesmo, logo na Apresentação do Problema, destaca que "Hodiernamente, já se deveria ter como certo que nós, em todo o legado de Aristóteles, não retornamos, nenhures, a um ponto em que Aristóteles tenha deixado de criticar a teoria das ideias de Platão, da mesma forma que não chegamos a nenhum ponto em que ele também tenha deixado de ser um platônico". Cfr. GADAMER, Hans-Georg. A idéia do bem entre Platão e Aristóteles. Tradução Tito Lívio Cruz Romano. São Paulo: Martins Fontes, 2009, p. 10. Um exemplo desta assertiva pode ser colhido no texto Aristotélico Sobre a Alma, em que apesar de Aristóteles criticar aqueles que como Platão "Esforçam-se apenas, todavia, por dizer que tipo de coisa é a alma; acerca do corpo que a acolhe, nada mais definem, como se fosse possível, de acordo com os mitos pitagóricos, que uma alma ao acaso se alojasse em qualquer corpo" $(407 \mathrm{~b}, 20)$ não deixa de concluir como Platão que existe uma natureza indivisível da alma que inclusive permite a unidade do corpo, ainda que para ele não se possa explicar a alma sem o corpo, por isso questiona e responde: "Então o que unifica a alma, se é indivisível por natureza? Não é, certamente, o corpo: antes parece, pelo contrário, que a alma unifica o corpo; pelo menos, o corpo dissipa-se e destrói-se com a partida da alma" (411b, 5). ARISTÓTELES. Sobre a alma. Tradução Ana Maria Lóio. São Paulo: Martins Fontes, 2013. p. 33-34.
} 
grande conjunto de argumentos sobre a substância de quais os melhores princípios devem guiar a comunidade.

Esta forma de raciocínio é fundamentalmente platônico e aristotélico. E por serem princípios podem ser objeto de desacordo entre os destinatários de sua aplicação, e tal desacordo somente pode ser resolvido mediante sua interpretação, logo a busca da resposta certa, nada mais é que o caminho normal deste método clássico de filosofar. Ronald Dworkin, embora não afirmando um conceito de princípios, coerente com a sua crítica às teorias semânticas do direito, leciona que o império do direito somente pode ser alcançado a partir da interpretação da Constituição ${ }^{9}$. As normas constitucionais que fixam direitos fundamentais, e sua efetividade não podem prescindir da sua interpretação, pois o fato de estarem fundados apenas em princípios não nega e nem é motivo suficiente para afirmar a falta de efetividade ou cogência dos direitos fundamentais, pelo contrário, é pela interpretação dos princípios que melhor e efetivamente se realizam, no mundo do direito, os direitos fundamentais.

Mas isto não significa que para Dworkin a teoria interpretativa deve se vincular a interpretação dos direitos fundamentais a partir, tão somente, do direito posto, porque a interpretação dos princípios não pode se bastar à letra da lei, mas deve considerar elementos da história, moral e ética, donde se origina o ordenamento jurídico, sem os quais não é possível realizar a interpretação jurídica, dando os exatos contornos do direito. Como o texto da Constituição não resolve os casos difíceis, é necessário que seus intérpretes procurem alguma outra coisa além das palavras para que possam realizar seu trabalho, Ronald Dworkin não apresenta um conceito da natureza dos princípios constitucionais, mas esta pode ser construída desde o seu conceito do direito como interpretação, a partir da prática do Poder Judiciário, em que põe em relevo o procedimento argumentativo judicial, não porque somente este seja importante, mas por reconhecer o papel central que essa forma argumentativa exerce dentro da prática jurídica, por serem mais explícitos e por terem uma influência sobre outras formas de discurso jurídico sem a mesma reciprocidade ${ }^{10}$.

Dworkin rejeita a interpretação literal como método de compreensão do direito e outras formas assemelhadas que denomina de teorias semânticas do Direito, cuja forma mais importante é o positivismo, porque o direito não pode ser uma simples questão de fato, ou apenas uma questão empírica, em vez de teórica. A exata compreensão do direito exige atitude interpretativa que não seja conversional, pois nesta, apenas se procura entender o que o autor pretende nos dizer, mas é preciso uma atitude interpretativa construtiva, conforme o modelo de interpretação criativa, relacionado às artes e práticas sociais, em que se destaca mais o propósito do que a causa,

\footnotetext{
${ }^{9}$ Importante registrar que para Dworkin "o Direito como integridade condena o ativismo e qualquer prática de jurisdição constitucional que lhe seja próxima. Insiste em que os juízes apliquem a Constituição por meio da interpretação, e não por fiat, querendo com isso dizer que suas decisões devem ajustar-se à prática constitucional, e não ignorá-la." DWORKIN, Ronald. O Império do Direito. São Paulo: Martins Fontes, 1999. p. 452. No original “Law as integrity condemns activism, and any practicy of constitucional adjucations close to it. It insists that justices inforce the Constitution through interpretation, not fiat, meaning that decisions must fit constitucional practice, not ignore it" DWORKIN, Ronald. Law's empire. Cambridge: Harvard University Press, 1986. p. 378. Como destaca Atienza, na atualidade das sociedades democráticas é fundamental explicar o Direito a partir do seu entendimento como argumentação, pois é fundamental observar que as formas de interpretação podem conduzir inclusive a revelar a nossa concepção de democracia, pela qual se exige que as decisões jurídicas sejam compreensíveis e aceitáveis pelos cidadãos, por isso considera que é fundamental afirmar que ao direito não importa unicamente os valores formais (a previsibilidade das decisões, a segurança jurídica), mas também valores materiais como a verdade e a justiça, e valores políticos da aceitação do consenso. Cfr. ATIENZA, Manuel. El sentido del derecho. Barcelona: Ariel, 2004. p. 263264.

${ }^{10}$ DWORKIN, Ronald. Law's empire. Cambridge: Harvard University Press, 1986, p. 15.
} 
espelhando o propósito do intérprete que o objeto ou prática analisada seja visto como o melhor exemplo possível do gênero a que pertence ${ }^{11}$. Aristóteles já tinha exposto a ideia de que para argumentar construtivamente é necessário estabelecer premissas do propósito que se pretende obter com o argumento. Assim, afirma que "Temos que distinguir tantos sentidos quantos sirvam ao nosso propósito. Por exemplo, se desejamos argumentar construtivamente, devemos propor os significados que sejam admissíveis e dividi-los somente naqueles que são úteis ao argumento construtivo" (ÓRGANON, Tópicos, L II, III, 110b1, 30-35) 12. Aristóteles havia alertado anteriormente que tal método argumentativo construtivo não se aplica a juízos racionais exatos, pois, nesses casos, o propósito de quem argumenta pouco importa ${ }^{13}$.

Dessa forma, argumentar ou interpretar construtivamente é essencial quando se pretende construir um objetivo universal segundo um propósito que realize o valor Justiça, ainda que outros caminhos sejam possíveis, por ser este o melhor caminho para alcançar uma finalidade ou propósito humano, por que a natureza do objeto exige a argumentação com vistas ao propósito que se pretende realizar. Ronald Dworkin, apesar de no livro "O Império do Direito" não ter o propósito de apresentar uma Teoria da Justiça, descreve como o direito atua para realizar os propósitos de determinada comunidade, segundo uma concepção de Justiça, destacando a relevância de diversas teorias da Justiça, como o marxismo ou utilitarismo, o que evidentemente exigem princípios que se utilizam para cumprir seus compromissos, sendo exatamente isso que ele reconhece ser o valor destas teorias $^{14}$.

Parte importante do seu estudo é a relação entre a interpretação e o Direito. Daí, inicia por apresentar argumentos sobre o que faz uma interpretação de uma prática social ser melhor que outra, e sobre como uma exposição jurídica promove uma mais satisfatória interpretação dessa complexa e crucial prática ${ }^{15}$. Aqui, já se pode constatar que sem determinados princípios não se pode interpretar os propósitos ou compromissos de determinado ordenamento jurídico, revelando a concepção de Justiça que lhe é inerente. Dworkin apresenta uma concepção dos Direitos Subjetivos, segundo a qual sua obrigatoriedade origina-se de decisões políticas do passado, de acordo com a melhor interpretação que elas podem significar para a comunidade, o que ajuda a explicar melhor as complexas relações entre o direito e outros fenômenos sociais. Portanto, o conteúdo do direito depende da moral e valores da comunidade ${ }^{16}$. Assim, para Dworkin e sua Teoria do Direto como Integridade, a concepção de Direitos Subjetivos, em que se incluem os direitos fundamentais, exige reconhecer que esses direitos pertencem às pessoas e que são patrocinados por princípios que promovem a melhor justificativa para a prática jurídica como um todo $^{17}$, como corolário, o papel central do Judiciário, dentro da sua concepção de direitos fundamentais.

Embora Dworkin destaque como a forma de exposição do Poder Judiciário é fundamental para a sua concepção do Direito, não ignora o papel do legislador no contexto da Teoria do Direito como Integridade. Apresenta primeiramente dois princípios morais práticos; o primeiro é o princípio da Integridade na Legislação, o qual exige que o legislador, ao criar as normas, mantenhase coerente com os princípios; o segundo é o princípio da Integridade nos processos judiciais, que

\footnotetext{
${ }^{11}$ DWORKIN, Ronald. Law's empire. Cambridge: Harvard University Press, 1986. p. 37, $51,52$.

${ }^{12}$ ARISTÓTELES. Órganon. Tradução Edson Bini. 2. ed. Bauru: Edipro, 2010. p. 378.

13 (ÓRGANON, Tópicos, L II, III, 110a1, 35 a 110b1).(ÓRGANON, Tópicos, L II, III, 110b1, 5) ARISTÓTELES. Órganon. Tradução Edson Bini. 2. ed. Bauru: Edipro, 2010. p. 377.

${ }^{14}$ DWORKIN, Ronald. Law's empire. Cambridge: Harvard University Press, 1986. p. 76.

${ }^{15}$ DWORKIN, Ronald. Law's empire. Cambridge: Harvard University Press, 1986. p. 86.

${ }^{16}$ DWORKIN, Ronald. Law's empire. Cambridge: Harvard University Press, 1986. p. 96.

${ }^{17}$ DWORKIN, Ronald. Law's empire. Cambridge: Harvard University Press, 1986. p. 152.
} 
exige dos juízes que as normas sejam analisadas e decididas de forma coerente com os princípios. Tal princípio explica como e por que deve ser permitido o poder especial como próprio das cortes, explicando por que os juízes devem compreender o corpo do direito que administram como um todo, em vez de um conjunto de decisões desconectadas que seriam livres para fazer ou alterar uma por uma ${ }^{18}$. Apresenta um terceiro princípio, o princípio da Integridade Política, fornecido para orientar a atuação judicial segundo o Direito como Integridade. Esse princípio revela a personificação da Comunidade ou do Estado que se dirige segundo princípios de equidade, justiça e devido processo legal. Assemelha-se ao caminho de entrega particular que as pessoas adotam determinadas convicções, ideais ou projetos, o que pode parecer uma forma de metafísica de má qualidade, mas que tomado como um princípio, impõe reconhecer que os agentes públicos autuam em nome de todos os membros da comunidade e a necessidade de tratar a responsabilidade coletiva como anterior à responsabilidade de cada uma das autoridades ${ }^{19}$.

Assim, em qualquer direção que se olhe, essa teoria do Direito como Integridade não pode separar-se de juízos morais da comunidade, segundo os princípios que elege como importantes. Como reconhece a existência de uma moralidade da comunidade, personificada no ordenamento jurídico, as pessoas passam a perceber que não são governadas somente por regras explícitas postas por decisões políticas do passado, mas por outras normas provenientes dos princípios que essas decisões assumem. Cria-se uma organicidade das normas públicas que podem expandir e contrair, conforme as necessidades. Essa sofisticação da comunidade a torna capaz de sentir e explorar o que esses princípios demandam em circunstâncias novas, sem necessidade de alteração legislativa ou jurisprudencial a cada ponto de conflito. O Direito como Integridade promove a fusão das circunstâncias políticas e privadas, uma como espírito da outra, promovendo o benefício de $\operatorname{ambas}^{20}$

A partir desta exposição, pode-se entender que, de acordo com o Direito como Integridade, as proposições jurídicas são verdadeiras se elas se apresentam ou derivam de princípios de Justiça, equidade e devido processo legal, que promovem a melhor interpretação construtiva da prática legal da Comunidade, e que tal concepção do direito somente faz sentido entre pessoas que também desejam equidade e justiça ${ }^{21}$.Assim sendo, não é possível navegar em mares tranquilos na interpretação constitucional. A Teoria do Direito como integridade não só permite mas alimenta diversas formas de conflitos substantivos ou tensão da melhor interpretação do direito e quando reconhece que a Integridade da atividade Judicial é soberana sobre o Direito. Isso ocorre porque deseja o reconhecimento de todos, como uma associação de princípios, como uma comunidade governada por uma singular e coerente visão de justiça, equidade e devido processo legal, nas devidas proporções ${ }^{22}$.

Pode-se concluir que a atitude filosófica própria de pensar platônico/aristotélico se manifesta em Dworkin, quando por meio de princípios busca cumprir o objetivo de realização dos direitos fundamentais, revelando os compromissos éticos da comunidade, de acordo com os princípios da Justiça, equidade e devido processo legal, e vai ao encontro do objetivo de realizar o valor Justiça de forma mais objetiva próprio da filosofia clássica, pela apresentação de conceitos substanciais dos valores éticos da comunidade. Este é o objetivo racional que exige princípios na prática interpretativa, elemento comum de Dworkin e as teorias platônicas e aristotélicas da Justiça,

\footnotetext{
${ }^{18}$ DWORKIN, Ronald. Law's empire. Cambridge: Harvard University Press, 1986. p. 167.

${ }^{19}$ DWORKIN, Ronald. Law's empire. Cambridge: Harvard University Press, 1986. p. 167, 175.

${ }^{20}$ DWORKIN, Ronald. Law's empire. Cambridge: Harvard University Press, 1986. p. 188, 190.

${ }^{21}$ DWORKIN, Ronald. Law's empire. Cambridge: Harvard University Press, 1986. p. 225-263.

${ }^{22}$ DWORKIN, Ronald. Law's empire. Cambridge: Harvard University Press, 1986. p. 404.
} 
onde a coerência somente pode ser alcançada pela unidade de princípios que evitem a contradição com os objetivos fundamentais da comunidade, segundo uma prática interpretativa construtiva.

\section{PROCESSO INTERPRETATIVO DE CONSTRUÇÃO DA UNIDADE E A FIGURA DO JUIZ HÉRCULES}

Para aprofundar a apresentação do papel do Poder Judiciário, na Teoria do Direito como Integridade, Dworkin apresenta a figura do juiz Hércules, que, apesar do nome de semideus, deixa de ser assustadora quando se reconhece nele apenas um método que reflete o encargo especial de um membro da comunidade, comprometido com os valores éticos da comunidade personificada no Estado, responsável por interpretar as Leis segundo a melhor luz, de acordo com os princípios que regem a comunidade. A interpretação constitucional é fundada em princípios, a busca da unidade é uma das tarefas mais árduas, daí o recurso a simbologia do semi-deus, figura mitológica de força e coragem incomum, mas que mesmo assim não escapa de sentir a dor humana, e de negar no lamento do sofrimento a sua força descomunal, quando pela morte inesperada é alcançado, ainda que movido pela vingança contra a esposa, como expressa Sófocles, as palavras de Hércules:

\footnotetext{
Vai, filho, coragem ! Tem dó de mim, digno de dó para muitos, que como uma moça berro em prantos - e isto ninguém pode afirmar me ter visto fazer: sempre segui meus males ingemente.

Mas eu, que era tal, me revelo agora pobre fêmea (SÓFOCLES. As Traquínias) ${ }^{23}$
}

Ora, se o Deus de força descomunal revela a sua fraqueza frente a dor humana, apesar das muitas provas de sua virilidade incomum, a tarefa interpretativa não está a salvo da imperfeição pois é tarefa humana, mas que precisa de um modelo de inspiração a guiar o desafio de realizar os princípios adotados pela comunidade. Pode-se concluir, para Dworkin, somente por meio de princípios se pode cumprir o desafio hercúleo de realização dos direitos fundamentais, em que os Tribunais exercem papel fundamental de mediante a sua interpretação promover a sua construção, revelando os compromissos éticos da comunidade, de acordo com os princípios da Justiça, equidade e devido processo legal.

Platão, nos seus Diálogos, não apresenta a figura do Juiz Hércules, mas também formula o seu modelo de agente que consegue expressar a coerência do todo, guiado pela razão, que é a figura de Sócrates, que se confunde com próprio destino da filosofia de colocar em praça pública os problemas vitais do ser humano. Logo, a figura Hércules ou Sócrates serve como recurso para explicitar que a coerência do todo não é uma tarefa fácil, mas é necessário seguir um modelo que permita atingir a coerência e a unidade para a construção da interpretação, porque as leis sempre surgem a fim de servir o ideal de justiça perseguido como necessidade humana ${ }^{24}$, entretanto, esta não é uma tarefa solitária, mas um paradigma a inspirar a comunidade.

Dentro do corpus platônico, a questão de que se há possibilidade de um governo legítimo sem leis torna-se falsa, pois a clara função pragmática da legislação é a ponta da sua fragilidade, sendo que ela sempre deve estar em função de um fim superior que somente se realiza se os seres humanos estiverem dispostos ao desafio, sejam governantes ou governados. O fundamental é perquirir como a moral dos cidadãos reflete a organização da polis, porque a ética dos cidadãos, na

\footnotetext{
${ }^{23}$ SOFOCLES. As Traquínias. Tradução Flávio Ribeiro de Oliveira. Campinas: Editora Unicamp. 2009. p. 101

${ }^{24}$ (PLATÃO. A República. 358e-359b) Cfr. PLATÃO. "A República". 3. ed. Tradução Carlos Alberto Nunes. Belém: Edufpa, 2000. p. 95. (Diálogos).
} 
filosofia clássica, se confundia com a ética perante a comunidade. A prudência é uma virtude, e não pode o ser humano se curvar como ser racional a uma legislação que concretize o injusto, ou interpretá-la de tal forma que permita contrariar sua natureza de ser que busca um fim supremo em sua existência, pois, dessa forma, abdicaria de sua racionalidade. Por isso, Aristóteles, apesar de seu método empirista de observação da realidade, não deixa, assim como Platão, de observar que existe um caráter finalista na atividade humana, como se pode observar desde o pórtico de sua obra Ética a Nicômaco, no Livro I, 1094 a, e $20^{25}$

Destarte, mesmo no modelo da justiça aristotélica definida, usualmente, como meio-termo entre dois extremos, retirada do Livro $\mathrm{V}^{26}$ de sua Ética (Ética à Nicômaco, 1129), a justiça não pode ser interpretada num caráter matemático simples, como simples proporção aritmética. A proporção aristotélica serve mais para demonstrar que a Justiça pode ser pensada como algo racional, como nas operações matemáticas, ainda que não pelo mesmo paradigma, por ser uma necessidade da razão humana. O alcance do meio-termo não basta para configurar, por meio dessa operação, a realização da Justiça, pois já no Livro II da mesma obra, Aristóteles faz questão de ressaltar que na realização das virtudes, da qual a justiça é a mais importante, deve-se necessariamente levar em conta as particularidades relativamente a nós, ou seja, deve-se levar em conta a aferição da justa medida, o meio-termo, principal e fundamentalmente considerando o ser humano como ser histórico, envolvendo juízos de equidade, à medida que o legislador não pode contemplar todas as situações da vida, essencial a perquirição do fim último das artes humanas ${ }^{27}$. A lei construída como elemento universal é sempre subordinada ao fím e não o inverso, o bem supremo da Justiça não pode ser curvar ao contingente (a lei). A realização da justiça, antes de depender das normas, depende do atuar dos seres humanos com senso de Justiça, sendo a norma apenas um parâmetro. E isso não quer dizer livre interpretação, mas atuação racional na aplicação da lei para a realização do fim de realizar a Justiça.

Inexiste Justiça se os seres humanos abdicam de atuar com virtude, deixando de ter o hábito de realizar a virtude. Não é por acaso que Aristóteles constrói uma ética da ação, prática da virtude. Assim, a realização da Justiça em Aristóteles torna-se coisa de uma sabedoria prática humana, ainda que guiada pela busca do supremo bem ${ }^{28}$. A filosofia clássica não distinguia a ética particular da ética pública, embora reconhecesse que havia espaços diferentes de como elas se praticavam, daí ser fundamental no pensamento aristotélico que os cidadãos praticassem a virtude, considerando que a sabedoria política e prática têm a mesma origem. ${ }^{29}$

Mesmo que se deixe de lado a pesquisa sobre se existe convenção fundamental dos seres humanos que legitima a ação legislativa do Estado, como fundamento racional, segundo o pensamento do jusnaturalismo, ou ainda que o fundamento da lei é a autoridade segundo a regra de competência, de acordo com o positivismo ${ }^{30}$, não se pode deixar de considerar que as regras

\footnotetext{
${ }^{25}$ ARISTÒTELES. Ética a Nicômaco. Tradução Leonel Vallandro e Gerd Bornheim. São Paulo: Abril Cultural, 1979. p. 49. (Coleção Os Pensadores, v. 2).

${ }^{26}$ ARISTÓTELES. Ética a Nicômaco. Tradução Leonel Vallandro e Gerd Bornheim. São Paulo: Abril Cultural, 1979. p. 121 (Coleção Os Pensadores, v. 2).

27 (Aristóteles, Ética a Nicômaco 1105, 35, 1106.10).(Aristóteles, Ética a Nicômaco, 1137b, 10). Cfr ARISTOTELES. Ética a Nicômaco. Tradução Leonel Vallandro e Gerd Bornheim. São Paulo: Abril Cultural, 1979. p. 72, 136. (Coleção Os Pensadores, v. 2).

${ }^{28}$ (Ética a Nicômaco, 1141b, 5-10) Cfr. ARISTOTELES. Ética a Nicômaco. Tradução Leonel Vallandro e Gerd Bornheim. São Paulo: Abril Cultural, 1979. p. 146. (Coleção Os Pensadores, v. 2).

${ }^{29}$ (Aristóteles, Ética a Nicômaco, 1141b, 25). ARISTOTELES. Ética a Nicômaco. Tradução Leonel Vallandro e Gerd Bornheim. São Paulo: Abril Cultural, 1979. p. 147. (Coleção Os Pensadores, v. 2).

${ }^{30}$ BOBBIO, Norberto. A Era dos Direitos. 19 reimp. Rio de Janeiro: Campus. 1992. p. 21.
} 
legais são, ou devem ser, feitas a fim de possibilitar a realização da justiça, como supremo bem que pode ser reconhecido como um princípio da integridade do Direito.

Este é o objetivo racional que exige princípios na prática interpretativa, elemento comum de Dworkin e as teorias platônicas e aristotélicas da Justiça, onde a coerência somente pode ser alcançada pela unidade de princípios que evitem a contradição com os objetivos fundamentais da comunidade, segundo uma prática interpretativa construtiva.

\section{RACIONALIDADE E LIMITES DA DISCRICIONARIEDADE JUDICIAL}

A figura do Juiz Hércules exerce, ainda, o papel relevante de sintetizar a função do Poder Judiciário, porque quando interpreta a lei, o Juiz Hércules não busca o que ele acredita ser o melhor resultado substantivo, mas sim a melhor justificativa para o evento legislativo do passado, segundo a melhor luz, reconhecendo este como ato de um poder legislativo democraticamente eleito, que deve justificar o ato como um todo e não apenas o final da história da comunidade ${ }^{31}$. Embora a Constituição seja diferente das leis ordinárias, por servir de fundamento das outras leis, o Juiz Hércules, sem abandonar $\Theta$ seu método, deve, necessariamente, ao realizar a sua interpretação, proceder a uma justificativa calcada nos mais profundos elementos do poder político da comunidade, o que significa que deve buscar as melhores razões de teoria política para sustentá$\operatorname{las}^{32}$.

Por ser o tema enfrentado por tal envergadura, a teoria do Direito como integridade não só permite mas alimenta diversas formas de conflitos substantivos ou tensão da melhor interpretação do direito e quando reconhece que a Integridade da atividade Judicial é soberana sobre o Direito. Isso ocorre porque deseja o reconhecimento de todos, que existe uma associação de princípios, que permite a comunidade ser governada por uma singular e coerente visão de justiça, equidade e devido processo legal, nas devidas proporções ${ }^{33}$.

O que se percebe aqui é que Dworkin introduz elementos que condicionam externamente a discricionariedade judicial, já que a tarefa do Poder Judiciário somente se revela racional se ao interpretar os princípios promove a realização dos direitos fundamentais, promovendo a apresentação de conceitos substanciais dos valores éticos da comunidade, o que demanda inclusive argumentos de teoria política. Quando Dworkin apresenta uma série de objeções às concepções que buscam remontar o pensamento do autor, como a fonte legitima da interpretação de Direito. Rejeitando terminantemente o Originalismo. Não é porque está delegando a tarefa interpretativa exclusivamente aos juízes, e que, portanto, haveria uma discricionariedade forte destes, pelo contrário, é porque prefere um caminho onde a democracia exerce um papel mais proeminente, que controla a ação do próprio legislador, e logicamente do Poder Judiciário, cuja função é realizar os valores éticos da Comunidade.

A Teoria do Direito como Integridade é um grande modelo abstrato de como se deve operar na interpretação das normas que caracterizam os fenômenos jurídicos, visando um bem maior, sabendo-se que estas não estão dissociadas da moral dos intérpretes, que estão vivos, porém deixando claro que estes fazem parte de um projeto de maior de história comum da comunidade. Um olhar mais atento e aberto permite vislumbrar um projeto ambicioso que permite reposicionar

\footnotetext{
${ }^{31}$ DWORKIN, Ronald. Law's empire. Cambridge: Harvard University Press, 1986. p. 339.

${ }^{32}$ DWORKIN, Ronald. Law's empire. Cambridge: Harvard University Press, 1986. p. 380-404.

${ }^{33}$ DWORKIN, Ronald. Law's empire. Cambridge: Harvard University Press, 1986. p. 404
} 
o direito entre as ciências sociais, como ciência que pode contribuir historicamente para a construção da resposta certa, frente aos grandes dilemas da humanidade.Por isso, para Dworkin não é necessário um grande retorno a um memorável momento da história, em que grandes homens e cidadãos se jogaram a esses objetivos coletivos, e construíram as Leis, que devem ser interpretadas necessariamente conforme postas originariamente, isto acaba por revelar um ponto de inflexão democrática. É neste contexto, que se pode compreender porque a relação à história não é um nada, inclusive deve servir para construir a interpretação do presente, segundo princípios que são racionalmente construídos de acordo com o propósito do intérprete, como membro da comunidade personificada.

É isto que permite construir um elemento objetivo para limitar a discricionariedade judicial, inclusive pelo dever de auto-contenção da atuação judicial, apesar do reconhecimento do aspecto de criação do direito, por meio dos Tribunais, ou seja, faz parte do processo de racionalidade, apresentar os critérios pelos quais o próprio juiz, demonstra a correção da decisão. A questão do controle da discricionariedade judicial não é central em Dworkin, não porque ele adote um modelo de discricionariedade judicial forte, mas porque ela mesma, está inserta e submetida no modelo que rege a atividade criadora dos Tribunais, que só se legitima quando protege os direitos fundamentais da comunidade. Ou seja, Dworkin retoma o modelo da filosofia clássica que a questão central não é o método, mas explicitar por meio de um modelo de ação prática, no que consiste determinados conteúdos substanciais, o que ele denomina de respostas certas, e segundo estes critérios se legitimam perante o Tribunal da Razão.

Portanto, é um grave erro interpretativo fazer a critica de Dworkin a partir do elemento da discricionariedade judicial, porque a importante questão do seu controle, só aparentemente é incontornável, pois ela mesma, não é uma questão central, porque segue a forma do pensamento clássico, onde o que importa são as respostas que o modelo permite produzir. Este sim o foco do pensamento teórico. Este tipo de erro de análise, por exemplo, é realizado por Loiane Prado Verbicaro, que, apesar de analisar e comparar de forma muito competente diversas teorias sobre o controle da discricionariedade judicial, comete o equívoco interpretativo de colocar Dworkin na mesma régua, deixando de observar que a questão de Dworkin passa pelo controle da discricionariedade judicial, mas apenas como parte do caminho para a construção da integridade do direito, ou, seja, reduz a questão de Dworkin a uma questão metodológica de se a discricionariedade judicial é forte ou fraca, quando na realidade o pensamento de Dworkin é uma proposta filosófica de como se construir a resposta certa por meio do Direito, o que é diferente de afirmar que esta seja a única resposta certa, o que negaria o aspecto de historicidade do direito ${ }^{34}$ Este tipo de crítica acaba sendo um elaborado meio de tentar enquadrar a obra sobre o prisma do positivismo, que coloca o papel central do direito na autoridade, quando a teoria de Dworkin justamente inicia pela crítica do positivismo, pois o seu escopo é apresentar uma forma de análise e construção do direito que fuja destas limitações teóricas. Segundo este objetivo ambicioso é que Dworkin precisa apresentar uma delimitação do que seria o Poder Criativo dos Tribunais, associado com outros critérios que regem o direito como integridade. Como se passa a demonstrar.

Inevitável, a alusão ao conceito de textura aberta do direito de Hebert Hart, segundo o qual existem áreas de conduta humana em que muitas coisas devem ser deixadas para ser desenvolvidas pelos tribunais ou pelos funcionários, os quais determinam o equilíbrio à luz das circunstâncias, entre interesses conflitantes que variam em peso de caso para caso, embora ressalve que essas

\footnotetext{
${ }^{34}$ Cfr VERBICARO, Loiane Prado. Judiicialização da Politica, Ativismo e Discricionariedade Judicial. Rio de Janeiro: Lumen Juris, 2017. pp. 387 e 389
} 
incertezas possam surgir relativamente da aplicabilidade de qualquer regra a um caso concreto. ${ }^{35}$ Aparentemente, trata-se da mesma função criadora dos tribunais pelo processo de interpretação que se pode reconhecer no autor citado, mas é fundamental observar que não se trata da mesma abordagem. Com efeito, Hart explica que a textura aberta do direito é dada aos juízes, mesmo aos do Supremo Tribunal "como partes de um sistema cujas regras são suficientemente determinadas na parte central para fornecer padrões de decisão judicial correcta" ${ }^{36}$. É uma roupagem mais elaborada de obtenção da completude do ordenamento jurídico, a partir da norma em que a interpretação apenas revela o seu conteúdo ${ }^{37}$. A função criadora pela interpretação, nesses casos, não é inerente à atividade do juiz no ato de julgar, mas uma exceção prevista pela lei e que assim deve ser cumprida fiel e limitadamente, segundo a autorização legislativa, para complementar o que já está previsto no ordenamento jurídico, concepção presente no direito brasileiro, segundo o art. 140, caput e parágrafo único, do CPC, que preceitua que o juiz não se exime de decidir sob a alegação de lacuna ou obscuridade do ordenamento jurídico, e que só decidirá por equidade nos casos previstos em lei.

O processo de criação do direito pelos juízes no pensamento de Dworkin é aquele que se realiza mediante o exercício da função interpretativa do direito, na aplicação aos casos concretos e que dá vida ao conteúdo da lei. Ela não apenas revela o conteúdo da lei, ou como se costuma dizer a "vontade do legislador", mas, reconhece como próprio da função de julgar a atuação interpretativa como essencial para que o direito assuma a sua verdadeira natureza e que não pode ser negada aos juízes. Por isso, essa atividade deve estar submetida a um limite racional, que se realiza por meio da fundamentação das decisões judiciais. É desse dever que trata a regra do art. 93, inc. IX, da CRFB. Essencial reconhecer que para Dworkin, deve haver um limite ao processo de interpretação judicial, para que lhe seja reconhecida a racionalidade da decisão judicial na realização da atividade interpretativa.

Ronald Dworkin, assim, busca limitar a interpretação judicial, apesar de reconhecer que o intérprete não pode ser retirado de seus pré-conceitos, a partir da demonstração dos mecanismos pelos quais o intérprete cumpre o dever de demonstrar que a sua decisão é fundamentada, pois realizada conforme o enredo das decisões judiciais que o antecedem, revelando a sua coerência com os princípios do Direito, demonstrando que a interpretação que apresenta coloca o objeto interpretado sob a sua melhor luz.Dworkin sustenta que os direitos fundamentais serão postos sob a melhor luz, segundo uma interpretação construtiva, que se qualifica por possuir um propósito e que expõe uma forma de ver o objeto interpretado que aponta na decisão a persecução da adoção de uma direção em vez de outra, a fim de torná-lo o melhor possível, um caso evidente de interação entre o objeto e o propósito ${ }^{38}$.

De acordo com esse objetivo, Dworkin apresenta os passos a serem realizados pelo magistrado no processo de decisão para uma correta interpretação, já que o Direito como integridade rejeita a velha questão se os juízes descobrem ou inventam a lei, mas declara que fazem as duas coisas ao mesmo tempo e nenhuma delas. O juiz deve identificar os direitos e deveres dos cidadãos criados pela comunidade personificada segundo uma concepção de justiça e igualdade e deve demonstrar que está sendo coerente com este propósito $^{39}$. O juiz não parte do nada. A

\footnotetext{
${ }^{35}$ HART, Herbert. L. A. O Conceito de Direito. Tradução A. Ribeiro Mendes. Lisboa: Fundação Calouste Gulbekian, 1994. p. 148.

${ }^{36}$ HART, Herbert. L. A. O Conceito de Direito. Tradução A. Ribeiro Mendes. Lisboa: Fundação Calouste Gulbekian, 1994. p. 154.

${ }^{37}$ BOBBIO, Norberto. Teoria do ordenamento jurídico. Brasília: Ed. UnB, 1995. p. 76,79,80, 117.

${ }^{38}$ DWORKIN, Ronald. Law's empire. Cambridge: Harvard University Press, 1986. p. 52.

${ }^{39}$ DWORKIN, Ronald. Law's empire. Cambridge: Harvard University Press, 1986. p. 225.
} 
comunidade já existe e o ato de decidir deve espelhar a sua história e desejos. A interpretação judicial integra a história contínua da cadeia do direito. Como autor e crítico desta obra coletiva que é o sistema jurídico, o magistrado precisa justificar as suas decisões nos princípios que regem a comunidade personificada. O primeiro passo para cumprir esse dever é que sua interpretação observe a dimensão da adequação demonstrando como o conjunto geral da comunidade interpreta determinado tema jurídico, ainda que possa detectar a sua incompletude ${ }^{40}$.

A segunda dimensão da interpretação exige que, após o primeiro passo, o juiz deva avaliar e fazer um juízo sobre quais dessas leituras interpretativas possíveis permite que o trabalho em desenvolvimento alcance o melhor resultado possível, considerando todos os aspectos envolvidos $^{41}$. O Poder Judiciário tem assim por missão na realização do seu propósito o dever de justificar suas escolhas que realiza no processo de decisão justificando-as segundo critérios de justiça, equidade e devido processo legal, o que demanda princípios jurídicos. Nesse ponto, podese observar que Ronald Dworkin reconhece na história um significado prospectivo, o que evita os retrocessos em matéria de direitos fundamentais. Dworkin ressalta que o Poder Judiciário possui a palavra final sobre o que é o direito, o que decorre da função de aplicar o direito aos casos concretos, pela interpretação construtiva. Assim, exerce o papel mais proeminente numa sociedade em que há o império do Direito, que é o de fixar os contornos dos direitos fundamentais, segundo a sua melhor luz.

A descrição de Dworkin sobre os elementos que legitimam a interpretação judicial e o seu papel criativo somente pode ser corretamente compreendida a partir de como esta função criativa dos tribunais não esteja isolada da história da comunidade, como no pensamento de Platão, cada parte da teoria somente faz sentido se compreendido como integrante de um grande esboço para a construção da verdadeira pólis, mediante recurso a razão cujo objetivo substancial legitima a escolha dos princípios que regem a comunidade, segundo valores eleitos como importantes para o bem estar da comunidade. Quando Dworkin afirma que uma importante parte do direito é fornecer princípios para as decisões dos Tribunais ${ }^{42}$, que promovem a integridade da Constituição, é porque o poder desarmado se legitima não para si, mas pela função de contribuir para a construção deste projeto de bem estar coletivo, numa sociedade onde impera o Direito.

Assim é melhor compreensível porque a interpretação construtiva impõe que se façam escolhas do porquê determinada descrição é melhor do que outra ou mais apropriada para a resolução do conflito em virtude da melhor teoria da democracia representativa ou algum outro fundamento de natureza abertamente política ${ }^{43}$, e, segundo essa linha de raciocínio, é que é possível promover uma coerência de ideais da comunidade, ajustando os seus interesses, sem contradições absurdas. Platão já havia apontado que quando se pensa com princípios é necessário buscar a unidade e coerência do pensamento, apesar do movimento da realidade que nos cerca, sempre mutável, pois de outra forma não é possível pensar o objeto da reflexão de maneira integral (Fedro, 249 B-C) $)^{44}$.

Refletindo essa necessidade de coerência, quando se raciocina com princípios é que a Teoria do Direito como Integridade de Dworkin não admite leis que ajustem os interesses das pessoas de uma comunidade segundo o local de onde habitam, atividade que exercem, sua condição de gênero, data de nascimento etc., em que tais critérios adotados pelo legislador não seguem uma razão ou

\footnotetext{
${ }^{40}$ DWORKIN, Ronald. Law's empire. Cambridge: Harvard University Press, 1986. p. 230

${ }^{41}$ DWORKIN, Ronald. Law's empire. Cambridge: Harvard University Press, 1986. p. 231

${ }^{42}$ DWORKIN, Ronald. Law's empire. Cambridge: Harvard University Press, 1986. p. 356.

${ }^{43}$ DWORKIN, Ronald. A Matter of principle. 9. ed. Cambridge: Harvard University Press, 2000. p. $163-164$.

${ }^{44}$ PLATÃO. Fedro.Texto grego John Burnet. Tradução Carlos Alberto Nunes. 3. ed. Belém: Edufpa, 2011 b. p. 115.
} 
princípio que lhes dê coerência interna, revelando contradições e dissensões flagrantes entre os diversos interesses em conflito, revelando-se arbitrárias (checkerboard statutes) ${ }^{45}$. Ao se reconhecer o caráter interpretativo do direito por meio de princípios, retoma Dworkin, o caminho que permite afastar antagonismos de princípios, e garante a sua exibilidade e proteção judicial, dispensando a necessidade da intervenção do legislador ${ }^{46}$.

Os tribunais devem atuar como Sócrates, que ao discutir os mais diversos temas, aparentemente desconexos, como a temperança no Carmides, ou a amizade no Lísis, ao mesmo tempo reporta a necessidade de proceder com conhecimento, e jamais devem afastar tal proceder de ser guiado pela ética ${ }^{47}$. Frase lapidar desse proceder, Platão descreve no diálogo Segundo Alcebiades, quando Sócrates enuncia "eu tinha razão em afirmar que a posse de qualquer conhecimento desacompanhado do bem só muito raramente poderá ser útil, e que na maioria das vezes prejudica seu possuidor" (PLATÃO, Segundo Alcebiades, 146, X, E) ${ }^{48}$

Exatamente por isso, essa tarefa dos tribunais é muito mais que uma apresentação de respostas particulares, mas também é meio de aperfeiçoamento moral da comunidade, porque os Tribunais são o meio racional, em que se espelham e refletem as grandes questões morais da comunidade. A própria comunidade pode controlar a discricionariedade judicial. Nesse conceito amplo, o Direito nunca pode ser pensado sem essa conexão entre substância e procedimento, pois o atuar nos tribunais sempre é formal, sem dever ser formalístico, porque ao cidadão comum não interessa saber como atuam os profissionais perante o tribunal, mas ao profissional deve interessar a melhor forma de demonstrar ao tribunal como a sociedade espelha o dilema moral.

Nesse sentido, há um papel fundamental do Direito em criar procedimentos para a realização dos princípios substanciais para a realização do valor justiça, harmonizar e coordenar essa relação é um dos desafios a superar. A abordagem de uma metodologia dialética levará à correta compreensão do fenômeno jurídico, tal como exposta no diálogo Parmênides de Platão, porque a relação entre o múltiplo e o uno, o semelhante e o dissemelhante, o movimento e o repouso, o nascimento e a destruição, para que sejam corretamente compreendidos precisam, antes de tudo, dar pouca razão à sua distinção, mas a forma como ocorre a relação entre eles, sem anular o que lhes é próprio, contribuindo para a correção do pensamento. ${ }^{49}$ Essa assertiva permite afirmar que antes de destacar a distinção entre o direito material e processual, o fundamental para a realização do valor Justiça, servindo-se dos institutos processuais na sua relação com o direito material, e conectados com os valores morais e história da comunidade. É desta relação dialética que se pode realizar o bem-estar humano pela interpretação do conflito posto frente ao Direito, alcançando a Justiça.

\footnotetext{
${ }^{45}$ DWORKIN, Ronald. Law's empire. Cambridge: Harvard University Press, 1986, p. 214

${ }^{46}$ DWORKIN, Ronald. Justice for hedgehogs. Cambridge: Belknap of Harvard University, 2011. p. 407.

${ }^{47}$ PLATÃO. Cármides - Lísis. Texto grego John Burnet. Tradução Carlos Alberto Nunes. 3. ed. Belém: Edufpa, $2015 c$. (Diálogos).

${ }^{48}$ PLATÃO. Primeiro Alcebiades - Segundo Alcebíades. Texto grego John Burnet. Tradução Carlos Alberto Nunes. 3. ed. Belém: Edufpa, 2015d. p. 197. (Diálogos).

49 (Parmênides, 136, b, c), PLATÃO. Parmênides - Filebo. Tradução Carlos Alberto Nunes. Belém: Edufpa, 1974. p. 34. (Diálogos, v. 8). Atento a esse conceito da dialética e o unindo ao pensamento hegeliano, Gadamer vai sintetizar que a hermenêutica é ela mesma a construção do acontecer e compreensão da coisa, por isso afirma: "Se nossa teoria hermenêutica busca reconhecer o entrelaçamento do acontecer e do compreender, terá de retroceder não somente até Hegel, mas também até Parmênides". Arremata ao descrever: "Assim, a dialética de pergunta e resposta sempre precedeu a dialética da interpretação. É aquela que determina a compreensão como um acontecer" (grifo no original). GADAMER, Hans-Georg. Verdade e Método I. Tradução Flávio Paulo Meurer. 14. ed. Petrópolis: Vozes; Bragança Paulista: Editora Universitária São Francisco, 2014, p. 594, 609.
} 
Um modelo de interpretação construtiva não nega e ressalta a proeminência dos tribunais numa sociedade em que impera o Direito. Nem por isso pode-se acreditar que o direito age para além da situação histórica dos homens, pois o direito não é como o receptáculo descrito por Platão, no Timeu ${ }^{50}$. Como não é o receptáculo, ao Poder Judiciário não basta declarar o direito para que assim, entrando os conflitos à sua análise e decisão, seja suficiente para ser alterada a realidade que se adequaria aos melhores princípios da comunidade, mas é necessário construir mecanismos pelos quais os direitos subjetivos sejam entregues aos cidadãos, realizando, historicamente, as decisões da comunidade, segundo os mecanismos do processo judicial porque, falhando o Poder Judiciário na entrega da prestação jurisdicional por não possuir mecanismos de execução adequados, sua legitimidade histórica não se realiza ${ }^{51}$.

A própria realização do processo é uma forma de controle da discricionariedade judicial, aqui para além do aspecto de decisão do conflito dentro do processo, pois sempre possível que a comunidade se volte contra o aparelho judicial, inclusive pelos mecanismos de desobediência civil.

\section{JUSTIÇA DISTRIBUTIVA E PROMOÇÃO DA IGUALDADE}

O sistema de Justiça Pública, possui um padrão normal de atuação, que envolve conflitos que Aristóteles denomina de Justiça Corretiva, em que o juiz atua como mediador entre os particulares, pois "a justiça corretiva será o intermediário entre a perda e o ganho", sendo os juízes chamados de mediadores ${ }^{52}$ (Ética a Nicômaco,V,4,1132 ), tal padrão de decisão é aplicável, sobretudo, entre iguais. Mas isso não impede, pelo contrário, torna necessário que determinadas situações se apoiem em modelos de Justiça Distributiva, que exige princípios que visam, justamente, corrigir desigualdades, segundo algum princípio que se elege como orientador da tomada de decisões. O próprio Aristóteles coloca entre aspas que esta Justiça Distributiva se dá "de acordo com o mérito" identificado pelos partidários de determinada filosofia-política. Assim, para realizar a Justiça Distributiva é fundamental a coerência de princípios que orientam a realização da solução dos conflitos, pela promoção da igualdade entre os seres humanos que se revelam segundo as escolhas políticas da comunidade, sem que isso implique igualdade absoluta, como exposto por Aristóteles $^{53}$

Quando se resgatam essas distinções da concepção de Justiça de Aristóteles, é possível compreender melhor porque Ronald Dworkin faz questão de discutir como os princípios do liberalismo são importantes para a realização do Direito como Integridade, por se tratar de concepção do direito que pauta conceitos de liberdade, igualdade, numa sociedade que não possui níveis elevados de degradação social, e que possui elevado consenso sobre a filosofia política que

\footnotetext{
50 "recebe todas as coisas, sem nunca assumir, de maneira alguma, o caráter do que entra nela. Por natureza, é matriz de todas as coisas; movimenta-se e diversifica-se pelo que entre nela, razão de parecer diferente, conforme as circunstâncias (Platão, Timeu, 50,c)PLATÃO. Timeu, Crítias, O Segundo Alcebíades, Hipias Menor. 3. ed. Tradução Carlos Alberto Nunes. Belém: Edufpa, 2001b. p. 90 (Diálogos).

${ }^{51}$ A crença que o direito pode sozinho alterar a realidade foi objeto da crítica de Engels e Kautsky ao "socialismo jurídico", cfr. ENGELS, Friedrich; KAUTSKY, Karl. O Socialismo jurídico. Tradução Livia Cotrim e Márcio Bilharino Naves. São Paulo: BoiTempo, 2012.

${ }^{52}$ ARISTÓTELES. Ética a Nicômaco. Tradução Leonel Vallandro e Gerd Bornheim da versão Inglesa de W. D. Ross. São Paulo: Abril Cultural, 1979. p. 126 (Coleção os Pensadores, v. 2).

53 (Ética.., V, 3, 20-30)ARISTÓTELES. Ética a Nicômaco. Tradução Leonel Vallandro e Gerd Bornheim da versão Inglesa de W. D. Ross. São Paulo: Abril Cultural, 1979. p. 125 (Coleção os Pensadores, v. 2).
} 
conduz os seus temas gerais. Entretanto, Dworkin, apesar de expressamente afirmar que uma economia igualitária é basicamente uma economia capitalista, quando expõe o conteúdo da igualdade, lhe é possível, sem contradição aparente, ao dissertar sobre a liberdade, afirmar ser inevitável que alguns recursos pertençam ao Estado, e que outros devem estar sob o controle público, para protegê-los contra fatores externos que corrompem a relação custo-oportunidade. Aduzir que determinadas regulações rígidas são necessárias para o controle da poluição não implica dizer que ele apoie ou negue diretamente o advento de uma sociedade comunista. ${ }^{54}$.

Entender os motivos pelos quais Dworkin precisa justificar como tais princípios se realizam ou devem se realizar, segundo o modelo político liberal dominante da sua comunidade, demonstrando a complexidade dessa filosofia, não impõe aceitar que somente por essa forma de explicação filosófica determinado princípio se torna válido, pelo contrário, quando é possível demonstrar que por variadas concepções de justiça não se pode negar a importância fundamental de determinado princípio é porque se estará mais próximo de sua essência racional, por impor-se como uma necessidade para que qualquer comunidade possa se estruturar adequadamente. Lembrase de que, mesmo quem tenta justificar o uso da força para legitimar determinado poder político, não pode ignorar o espírito de liberdade que habita nos homens. Assim, após um breve resgate de como os valores da comunidade influenciam o processo de decisão política, Nicolau Maquiavel, por exemplo, registra que um dos maiores desafios do Príncipe que deseja manter um reino conquistado ocorre quando ao:

se tornar senhor de uma cidade habituada a viver em liberdade e não a reduzir a ruína será mais cedo ou mais tarde arruinado por ela: pois sempre se abrigam nas rebeliões o nome da liberdade e suas antigas leis, coisas que nunca se esquecem, nem pela duração do tempo, nem por quaisquer benefícios ${ }^{55}$

Numa sociedade com maior tradição, organização e distribuição de bens sociais, com menos desigualdade, ainda que passando por situações históricas que põe em cheque o modelo, talvez seja mais fácil ou menos difícil construir essa relação com os princípios políticos dominantes na comunidade, pois mais fácil reconhecer os princípios políticos da comunidade como um todo. Entretanto, isso não torna o resultado mais factível historicamente, talvez seja justamente o contrário o que torna o desafio permanente. Nesse contexto, apontar as escolhas políticas da comunidade, tem um papel relevante quando se deseja analisar contextos cuja as respostas precisam de uma maior envergadura, segundo o modelo de justiça distributiva aristotélico, atento a este aspecto, o meio que Dworkin encontra para cumprir esse objetivo é justamente analisando como determinados princípios liberais se apresentam em sua comunidade, ainda que sem esgotar todo o

\footnotetext{
${ }^{54}$ Cfr. DWORKIN, Ronald. Justice for hedgehogs. Cambridge, Massachusetts: Belknap of Harvard University, 2011, p. 357-375. Ainda, sobre a força do liberalisno no pensamento de Dworkin, conferir, por exemplo, o Capítulo 9, do livro de Dworkin, Ronald. A Matter of principle. Cambridge: Harvard University Press, 2000. p.205-220.Um bom exemplo de como o liberalismo possui elevado consenso na comunidade estadunidense é a exposição que Cass Sustein realiza para demonstrar como determinadas ações paternalistas do Estado não ferem os princípios que movem essa filosofia, sendo inclusive bem-vindos por promover o bem-estar das pessoas, segundo problemas concretamente enfrentados pela comunidade, mantido o direito de livre escolha das pessoas, o que ele denomina de "soft paternalism". Isso não quer dizer que uma sociedade guiada pelo liberalismo não conheça a intervenção estatal, mas o interessante dessa sua exposição é tornar possível perceber uma consciente busca de legitimar essas modalidades de interferências, para sugerir as melhores escolhas para a comunidade, visando o bem-estar de todos, segundo os princípios desse pensamento filosófico, o que acaba ultrapassando os limites dessa filosofia, segundo uma argumentação racional. Cfr. SUSTEIN, Cass. R. Why Nudge? The Politicas of Libertarian Paternalism.New Haven: Yale University Press. 2014. 55 MAQUIAVEL, Nicolau. O Príncipe. Tradução Mauricio Santana Dias. São Paulo: Penguin Classics; Companhia das Letras, 2010. p. 61.
} 
seu espectro. Numa sociedade cujos princípios de filosofia política que dominam a sociedade são melhor consolidados, é mais fácil demonstrar como os princípios jurídicos se abraçam com determinados princípios de uma filosofia política, como: o liberalismo, o marxismo, o capitalismo etc., mas isto não veda a possibilidade, que determinados temas possam ser considerados de forma comparativas por esses diversos pensamentos filosóficos, e construir como tais princípios se apresentam como racionais em várias concepções filosóficas e se afirmam no Direito. Não existe uma concepção de filosofia política que pode ser a priori considerada a melhor, ou que dite a necessidade de considerar determinado conflito sob o olhar de múltiplas fontes filosóficas, a questão é mostrar como se mantém a unidade da argumentação.

A especificidade da ciência do Direito na contribuição à Justiça distributiva, concretamente assentada, possível de ser construída, está justamente em que o processo judicial é naturalmente aberto pela contraditório à diversidade e debate das concepções políticas. Eleva-se a argumentação jurídica a um patamar singular de interpretação, que por isso mesmo deve ser aberta a ouvir e refletir as concepções filosóficas não dominantes, para melhor construir a resposta certa. Nessa linha, quando se usa a filosofia Aristotélica, cuja obra A Política, por exemplo, apesar de reconhecer a escravidão como algo natural, e por corolário, os escravos são colocados fora do governo, reservado somente aos cidadãos livres, é necessário se buscar a essência do argumento que é entender quem pode conduzir a política, que tem por objetivo construir a felicidade dos cidadãos, derivada do grau de igualdade que os homens livres elegem como o mais adequado, pois "a sociedade é uma reunião de seres semelhantes que tem por fim a vida mais perfeita possível"(A Política, VII, Cap. VII, $\left.\S 2^{\circ}, 35\right)^{56}$.

O objetivo não é extrair a verdade ou falsidade dos argumentos aristotélicos, cuja interpretação desse princípio maior permite deduzir quando as formas de governo degeneram negando a realização do objetivo da Política, mas não se pode negar que Aristóteles, segundo o seu método de observação da realidade, discute a organização do Estado com o fim de construir a igualdade possível à sua época, exatamente o papel colhido ao Direito, que uma visão histórica permite avaliar criticamente o grau de realização da igualdade em determinada sociedade, exatamente o que é proposto por Dworkin.

A utilização do conceito de governo democrático, segundo Aristóteles, é baseado no conceito de cidadão, que nada mais é "aquele que pode ser juiz e magistrado"(A Política, III, Cap. $\left.\mathrm{I}, \S 4^{\circ}, 20\right)^{57}$, o lugar onde impera a igualdade de acesso de todos ao poder, pois "seria ridículo negar autoridade exatamente àqueles que têm nas mãos o poder soberano"(A Política, III, Cap. I, $\left.\S 5^{\circ}, 30\right)^{58}$, donde a democracia é onde melhor se realiza o conceito de cidadão, porque destinada a eliminar toda barreira de acesso ao poder e, obviamente, de desigualdade, e que "resulta claramente que o cidadão não é o mesmo em todas as formas de governo, e que, por isso, é na democracia, principalmente, que ele se adapta à nossa definição" (A Política, III, Cap I, $\S 6^{\circ}$, $1275 \mathrm{~b}, 5)^{59}$.O fato de na democracia o poder soberano estar na mãos dos pobres, segundo Aristóteles, é um alerta que seu desafio permanente é ampliar o espectro dos que podem ser considerados semelhantes, sem alterar o princípio democrático, em que a maioria governa, promovendo maior igualdade na distribuição das riquezas porque, estando o poder nas mãos da maioria, se forem iguais, melhor se realiza a democracia.

O desafio de repensar a democracia, na atualidade, a todo instante, é porque os pobres

\footnotetext{
${ }^{56}$ ARISTÓTELES. A Politica. Tradução Nestor Silveira Chaves. 2. ed. Bauru: Edipro, 2009. p. 243.

${ }^{57}$ ARISTÓTELES. A Política. Tradução Nestor Silveira Chaves. 2. ed. Bauru: Edipro, 2009. p. 80.

${ }^{58}$ ARISTÓTELES. A Política. Tradução Nestor Silveira Chaves. 2. ed. Bauru: Edipro, 2009. p. 81.

${ }^{59}$ ARISTÓTELES. A Política. Tradução Nestor Silveira Chaves. 2. ed. Bauru: Edipro, 2009. p. 81.
} 
ainda são a maioria, logo, fonte permanente de desigualdade, mas o fundamental é perceber como o pensamento aristotélico pode ajudar a ciência do direito a construir princípios que resolvam os problemas de desigualdade, pela interpretação dos valores: igualdade, liberdade e solidariedade, segundo a vigente concepção democrática, para aperfeiçoar a sociedade política. Ora, se mesmo Aristóteles, que reconhece a escravidão como algo natural, não exclui ao servo a sua dignidade de ser humano, apenas discute os níveis de virtude necessários a cada grupo, afirmando que "Exigir virtude em um e não exigir em outro seria absurdo" (A Política, I, Cap. IV, $\S 10)^{60}$, tanto mais relevante é para uma concepção de democracia, em que a escravidão é inaceitável, a construção histórica da igualdade como desafio irrenunciável, em que a ideia de dignidade humana é a alavanca que não permite legitimar nenhuma diferença decorrente da capacidade de poder político, econômico, etnia, condição social, porque os seres humanos são iguais em virtude.

Isso permite a Aristóteles reconhecer o papel fundamental da ética de construir o bemestar comunitário, e afirmar que "haveria comunidade e alguma espécie de justiça mesmo que o Estado não existisse"'(Ética a Eudemo, Livro VII, 10, 25-30) ${ }^{61}$, porque o respeito a natureza humana é o fundamento que legitima toda forma de organização política. Não se trata de discutir o acerto da concepção aristotélica em não separar a moral da política, mas de reconhecer que, quando se atribui aos tribunais o papel de instrumento público de solução dos conflitos, atraindo-se a utilização de critérios de justiça distributiva, é porque, sob este aspecto, já não se pode mais despregar as decisões de argumentos políticos que exigem interpretação da concepção ética da democracia da comunidade política, pois somente assim pode-se coordenar os diversos interesses que compõe a sociedade, arrastando-os para o mesmo fim que, segundo a concepção aristotélica, permitiria formar uma cidade virtuosa. ${ }^{62}$ Como a função dos direitos políticos é permitir discutir o destino da comunidade e não dos indivíduos, sob o ponto de vista da contribuição para o avanço da democracia, a sua garantia é condição importante e necessária para a melhor defesa dos direitos fundamentais, por garantir aos grupos desiguais mecanismos de acesso ao Poder ${ }^{63}$.

Ronald Dworkin empreende esta distinção e exercita o desenvolvimento destes argumentos de justiça distributiva, quando, por exemplo, afasta as contradições entre a igualdade, que mesmo quando alçada ao patamar de uma virtude soberana, não importa a negação ou contraponto limitador do direito de liberdade, pelo contrário, argumenta como melhor concepção de igualdade distributiva permite a melhor proteção da liberdade como direito individual o qual o cidadão pode escolher o melhor para a própria vida, segundo uma concepção de igual consideração e respeito pela comunidade politica(Estado $)^{64}$. Decorrente desse desafio permanente da realização

\footnotetext{
${ }^{60}$ ARISTÓTELES. A Política. Tradução Nestor Silveira Chaves. 2. ed. Bauru: Edipro, 2009. p. 34.

${ }^{61}$ ARISTÓTELES. Ética a Eudemo. Tradução Edson Bini. São Paulo: Edipro, 2015. p. 280.

62 (A Política, Livro VII, Cap. XII, § 5) ARISTÓTELES. A Política. Tradução Nestor Silveira Chaves. 2. ed. Bauru: Edipro, 2009. p. 253.

${ }^{63}$ Por isso que Bobbio ao analisar o pensamento de Hegel, que concebe o Estado com um fim superior, destaca a estreita relação entre o conceito de Constituição e a organização do todo, em que as várias partes, ainda que desiguais, compõe o povo. Cfr. BOBBIO, Norberto. Estudos sobre Hegel: Direito, sociedade civil, Estado. 2. ed. São Paulo: Brasiliense, 1995. p. 99. Essa visão permite entender melhor porque, apesar destas particularidades, somente pode haver o efetivo respeito aos direitos sociais e individuais quando os direitos políticos são exercidos com liberdade, onde todos possam influir no destino da comunidade. Assim, por exemplo, Carlos Ayres Britto aponta que, sob o manto da concepção de Humanismo, deve-se buscar uma verdadeira fusão ente a vida coletiva e a democracia, elevando o status civilizatório da comunidade, promovendo os direitos de todos e especialmente dos menos favorecidos. Cfr. BRITTO, Carlos Ayres. O Humanismo como categoria constitucional. Belo Horizonte: Forum, 2007, Cap. IV, p. 3135.

${ }^{64}$ DWORKIN, Ronald. Sovereign virtue: the theory and practice of equality. Cambridge: Harvaard University Press, 2002. especialmente Capitulo 3, O lugar da Liberdade, p. 120-183.
} 
da Justiça distributiva é que mesmo uma sociedade mais bem estruturada precisa ser coerente com seus princípios fundamentais de maneira mais rigorosa, e isso é que torna legítimo que Dworkin, a partir do princípio da dignidade humana, segundo os princípios do intrínseco valor do ser humano e da responsabilidade pessoal, que exige uma consciente realização das próprias escolhas, construa uma ácida crítica à democracia estadunidense, inclusive propondo reformas do processo eleitoral e da Corte Suprema dos EUA, necessárias para aperfeiçoar substancialmente a democracia de sua comunidade, para além do critério majoritário ${ }^{65}$

Da mesma forma, Dworkin faz um longo exercício de como esse princípio da dignidade humana e seus desdobramentos apresenta-se como fundamental para compreender adequadamente a relação entre a ética e a moral subjacentes a diversos temas fundamentais para o bem-estar da comunidade, possibilitando não somente uma boa vida, como um bem viver ${ }^{66}$. Essa mesma linha argumentativa é que permite que a teoria do Direito como Integridade de Dworkin, ao discutir temas como a eutanásia, aborto, liberdade individual, possa relacioná-los com outros temas, como as políticas afirmativas etc.,segundo determinados princípios interpretativos adotados, pela interpretação constitucional, na fundamentação das decisões do Tribunal Constitucional. Porque reconhece que é possível que, uma vez aceito um princípio pela comunidade jurídica, este não só pode, mas deve ser aplicado em casos que aparentemente não tem nenhuma relação entre si, mesmo nos mais diversos campos jurídicos, segundo argumentação racional que revele a unidade do ordenamento jurídico. ${ }^{67}$

Entender tal aspecto dá uma visão melhor do contingente do operar do Direito como elemento essencial na interpretação construtivista, decorrente da natural limitação argumentativa na própria historicidade dos tribunais. Entretanto, ao mesmo tempo isso impõe o dever de argumentar ao limite, para que sua contribuição ao desenvolvimento da comunidade política se realize e esteja transparente, até como fonte de pesquisa para a comunidade em geral, passível de uma crítica mais ácida, mesmo por agentes externos da comunidade jurídica, e que deve ser considerada pelos agentes jurídicos, suscitando a necessidade de seu aperfeiçoamento, objetivo da ciência jurídica. Como visto, não se deve acreditar que todos os problemas da comunidade se resolvem nos tribunais, mas não implica fuga do desafio de enfrentar os temas mais gerais da comunidade por meio da análise do Direito, e a opção de limitar, conscientemente, a sua especulação filosófica, sem ignorar que os atores sociais adotam determinados princípios de filosofia política que influenciam a legislação e outros aspectos do Direito.

Inegável que a função do direito é revelar a melhor interpretação possível, mediante fundamentação racional e segundo mecanismos procedimentais, permitindo ao Poder Judiciário contribuir historicamente para a realização da Justiça, revelando as escolhas políticas e éticas da comunidade $^{68}$. De fato, uma concepção de Justiça Distributiva, como exposto, é fundamental para a melhor compreensão dos objetivos que se pretendem alcançar, para que o Judiciário seja adequado às novas demandas da sociedade pós-industrial, apresentando-se como o guardião célere e competente na tutela dos interesses comunitários. Quando assim procede, o tribunal expressa

\footnotetext{
${ }^{65}$ DWORKIN, Ronald. Is Democracy possible here? principles for a new political debate. Princeton: Princeton University Press, 2008.

${ }^{66}$ DWORKIN, Ronald. Justice for hedgehogs. Cambridge: Belknap of Harvard University, 2011.

${ }^{67}$ Cfr. DWORKIN, Ronald. Life's dominion: an argument about abortion, euthanasia, and individual freedom. New York: Vintage Books,1994. Especialmente o capítulo 5, p. 118-146.

${ }^{68}$ Como já afirmou Dallari "Na verdade o direito sempre é político, por suas origens e por seus efeitos sobre os indivíduos enquanto participantes necessários da convivência, com seus valores e seus interesses que só se realizam no social, bem como sobre os grupos sociais e a sociedade como um todo". Cfr. DALLARI, Dalmo de Abreu. O Poder dos Juízes. 3. ed. São Paulo: Saraiva, 2008, p. 59.
} 
escolhas políticas já tomadas pela comunidade, gerando ganhos para a cidadania, por permitir decidir sobre os Direitos que possuem, sem afetar os campos de decisão política tomada pelo Poder Legislativo e Executivo e segundo uma consistente argumentação política sustentada com base neste princípio ${ }^{69}$

\section{CONCLUSÃO}

A tarefa de encontrar conexões entre a obra de Platão, Aristóteles e Dworkin, permite observar como a originalidade está muitas vezes em retomar caminhos clássicos que ainda influenciam o pensamento ocidental, seguindo as grandes linhas no encontro do supremo bem, ou a resposta certa, para que os seres humanos possam viver plenamente a sua humanidade, objeto desde sempre da filosofia. Somente seguindo este caminho é possível reposicionar o papel do Direito no conjunto das ciências humanas, reivindicando-se um objeto nobre, que é a construção racional dos princípios jurídicos como espelho das escolhas éticas da comunidade. Para obter este resultado, as abordagens sobre direitos fundamentais, devem seguir o seguinte roteiro de análise, como resultado de um caminhar filosófico-jurídico, para a plena realização dos Direitos Humanos:

1-A Superação da Madição de TOT na interpretação dos direitos fundamentais, permite construir o seu conteúdo substancial para além da leitura do texto constitucional, exprimindo os propósitos e valores da comunidade, reconhecendo-se o Direito como a prática interpretativa mais competente para trazer objetividade as escolhas éticas da humanidade.

2- A Atitude Filosófica e Interpretação Construtiva frente aos conflitos normativos, permite identificar os princípios jurídicos que revelam a verdade, na formulação da resposta certa, argumentando-se de forma construtiva para encontrar substância dos direitos fundamentais, como autênticos direitos subjetivos.

3. O Processo Interpretativo de Construção da Unidade deve ser comprometido com os valores éticos da comunidade personificada no Estado, e como tal na interpretação das Leis, fundada em princípios, na busca da unidade, por mais difícil que seja a tarefa, ante a imperfeição humana, e o desafio de realizar o ideal de justiça da comunidade.

4. A Racionalidade e Limites a Discricionariedade Judicial que enfatiza a função do Poder Judiciário, responsável pela última palavra na interpretação da lei, exige que se indique os critérios racionais que limitam a discricionariedade judicial, e que se legitima quando protege os direitos fundamentais da comunidade, que podem ser investigados segundo critérios racionais.

5. A Justiça Distributiva e Promoção da Igualdade são essenciais a plena realização dos Direitos Fundamentais, pois a atuação pelo modelo de Justiça Distributiva exige princípios que visam, corrigir desigualdades, segundo princípio que se elege como orientador da tomada de decisões, em acordo com as escolhas políticas da comunidade, sem que isso implique igualdade absoluta. Exige uma reflexão sobre o modelo político dominante na comunidade, mas sem se fechar a análise de outros pensamentos minoritários, demonstrando como os princípios jurídicos se abraçam com determinados princípios da filosofia política. Uma modelo de proteção dos direitos fundamentais deve sempre incluir o princípio de governo democrático, baseado no conceito de cidadania, onde impera a igualdade de acesso de todos ao poder, expressão do poder soberano popular, destinada a eliminar toda barreira de acesso ao poder e, a eliminar as desigualdades. A construção dos direitos políticos, permitem discutir o destino da comunidade e não dos indivíduos, mas sem importar, contradições com os direitos individuais, onde a melhor concepção de igualdade

${ }^{69}$ DWORKIN, Ronald. A Matter of principle. 9. ed. Cambridge: Harvard University Press, 2000. p 27, 57. 
distributiva permite a melhor proteção do direito individual o qual o cidadão pode escolher o melhor para a própria vida, segundo uma concepção de igual consideração e respeito pela comunidade politica(Estado).

Estes princípios morais práticos do modelo de interpretação construtiva, permitem elevar a ciência do direito a um patamar diferenciado entre as ciências sócias, por ser a ciência responsável por dar objetividade às escolhas morais da comunidade personificada. O próprio ensino do Direito deve ser impactado para ter como objeto analisar os grandes temas éticos enfrentados pelos Tribunais, Direito material e processual são só ferramenta da interpretação, cujas interfaces revelam as escolhas éticas da sociedade histórica, no caminho de alcançar a resposta certa, assim, o Direito é uma arqueologia do presente das escolhas éticas do passado, reflexas no presente e prospectivas do futuro.

Ao se definir como objetivo da ciência jurídica a promoção dos direitos fundamentais, esta casa com a direção apontada no caso brasileiro desde o preâmbulo constitucional, cujo desiderato é construir um Estado Democrático, destinado a assegurar o exercício dos direitos sociais $e$ individuais, a liberdade, a segurança, o bem estar, o desenvolvimento, a igualdade e a justiça, como valores supremos de uma sociedade fraterna, pluralista e sem preconceitos, fundada na harmonia social e comprometida, na ordem interna e internacional, com a solução pacífica dos conflitos. E neste passo, uma interpretação sistemática das leis exige se reportar aos princípios constitucionais da República Federativa do Brasil, tanto por ser o documento jurídico-político fundamental do país, mas, sobretudo, porque somente pela sua interpretação se permite que o Estado Democrático de Direito avance nos seus fundamentos, notadamente de cidadania, dignidade humana, valores sociais do trabalho (art. $1^{\mathrm{o}}$ da CRFB).

Isso permite obter fôlego teórico para uma análise que vá além de um ordenamento jurídico nacional, fundamental para a interpretação dos Tratados Internacionais de Direitos Humanos e sua relação com os ordenamentos nacionais, essencial para a correta interpretação do direito brasileiro, cujo direito positivo não estabelece relação de condicionalidade entre os direitos fundamentais, além de afirmar que possuem aplicação imediata, cujos direitos expressamente previstos não excluem outros decorrentes do regime e dos princípios que adota, ou dos tratados internacionais em que a República Federativa do Brasil seja parte, tal como previsto nos $\S \S 1^{\circ}$ e $2^{\circ}$ do art. $5^{\circ}$. da CRFB.

Nesse diapasão, considera-se que a profunda desigualdade que ainda impera na sociedade brasileira e que envergonharia até o mais convicto liberal do século XVIII facilita a dispensa de maior envergadura teórica para justificar determinadas conquistas históricas que vão se afirmando para além do modelo de filosofia política adotado, eventualmente, pelo intérprete, cujo papel no Direito é refletir o processo interpretativo da realização histórica da Justiça, como exigência racional, fundamentado segundo argumentos de filosofia política, debatido e demonstrado por diversos viés a sua racionalidade. De fato, é relevante declarar que, segundo a tradição brasileira, não se pode negar a função dos tribunais em dizer o direito, portanto, definir o contorno dos direitos fundamentais sem que isso afete a função do Poder Executivo e Legislativo, até porque esses Poderes são independentes e harmônicos, conforme postulado no art. $2^{\circ}$. da CRFB.

Reconhecer essa função interpretativa construtiva do Poder Judiciário é particularmente importante num país cuja história é marcada por descontinuidades institucionais e longos períodos de ditadura, que ensinou que a salvaguarda dos direitos fundamentais somente poderá ter efetiva defesa com uma magistratura que possa, livremente, exercer esse mister, e quando, nesse campo, falha a racionalidade, decididamente é reflexo da grave falha na construção da comunidade personificada para a realização do valor Justiça. 
$\mathrm{O}$ atual conceito de democracia coloca a humanidade no caminho de ser governada por um pensar filosófico, em que o Poder desarmado exprima escolhas éticas racionais, para que aqueles que não tendo acesso a outras formas de Poder tenham segurança que este é de igual acesso a todos, o que torna relevante o fortalecimento do papel das Cortes Internacionais de Justiça, em diálogo permanente como as Cortes Locais, demonstrando que a força nunca é boa fonte de respostas, mas sim a Justiça, pelo que a sociedade escolheu viver sob o o império do Direito.

\section{REFERÊNCIAS}

ARISTÓTELES. Metafísica. Tradução Vinzenzo Cocco e notas de Joaquim de Carvalho. São Paulo: Abril Cutural, 1979. Livro II.(Coleção os Pensadores).

ARISTÓTELES. Metafísica. Sobre a alma. Tradução Ana Maria Lóio. São Paulo: Martins Fontes, 2013.

ARISTÓTELES. Metafísica. Órganon. Tradução Edson Bini. 2. ed. Bauru: Edipro, 2010.

ARISTÓTELES. Metafísica. Ética a Nicômaco. Tradução Leonel Vallandro e Gerd Bornheim. São Paulo: Abril Cultural, 1979. (Coleção Os Pensadores, v. 2).

ARISTÓTELES. Metafísica. A Política. Tradução Nestor Silveira Chaves. 2. ed. Bauru: Edipro, 2009.

ARISTÓTELES. Metafísica. Ética a Eudemo. Tradução Edson Bini. São Paulo: Edipro, 2015.

ATIENZA, Manuel. El sentido del derecho. Barcelona: Ariel, 2004.

BOBBIO, Norberto. A Era dos Direitos. 19 reimp. Rio de Janeiro: Campus. 1992.

BOBBIO, Norberto. Teoria do ordenamento jurídico. Brasília: Ed. UnB, 1995.

BOBBIO, Norberto. Estudos sobre Hegel: Direito, sociedade civil, Estado. 2. ed. São Paulo: Brasiliense, 1995.

BRITTO, Carlos Ayres. O Humanismo como categoria constitucional. Belo Horizonte: Forum, 2007.

DWORKIN, Ronald. O Império do Direito. São Paulo: Martins Fontes, 1999.

DWORKIN, Ronald. Law's empire. Cambridge: Harvard University Press, 1986.

DWORKIN, Ronald. A Matter of principle. 9. ed. Cambridge: Harvard University Press, 2000.

DWORKIN, Ronald. Justice for hedgehogs. Cambridge: Belknap of Harvard University, 2011.

DWORKIN, Ronald. Sovereign virtue: the theory and practice of equality. Cambridge: Harvaard 
University Press, 2002.

DWORKIN, Ronald. Is Democracy possible here? principles for a new political debate. Princeton: Princeton University Press, 2008.

DWORKIN, Ronald. Life's dominion: an argument about abortion, euthanasia, and individual freedom. New York: Vintage Books, 1994.

ENGELS, Friedrich; KAUTSKY, Karl. O Socialismo jurídico. Tradução Livia Cotrim e Márcio Bilharino Naves. São Paulo: BoiTempo, 2012.

GADAMER, Hans-Georg. A idéia do bem entre Platão e Aristóteles. Tradução Tito Lívio Cruz Romano. São Paulo: Martins Fontes, 2009.

GADAMER, Hans-Georg. Verdade e Método I. Tradução Flávio Paulo Meurer. 14. ed. Petrópolis: Vozes; Bragança Paulista: Editora Universitária São Francisco, 2014.

HART, Herbert. L. A. O Conceito de Direito. Tradução A. Ribeiro Mendes. Lisboa: Fundação Calouste Gulbekian, 1994.

MAQUIAVEL, Nicolau. O Príncipe. Tradução Mauricio Santana Dias. São Paulo: Penguin Classics; Companhia das Letras, 2010.

NUNES, Benedito. A superação da Filosofia In O Dorso do Tigre. São Paulo: Ed 34, 2009.

PLATÃO. Fedro. Texto grego John Burnet. Tradução Carlos Alberto Nunes. 3. ed. Belém: Edufpa, $2011 b$.

PlATÃo. Fedro. A República. 3. ed. Tradução Carlos Alberto Nunes. Belém: Edufpa, 2000. (Diálogos)

PLATÃO. Fedro. Teeteto - Crátilo. 3. ed. Tradução Carlos Alberto Nunes, Belém: Edufpa, 2001a. (Diálogos).

PLATÃo. Fedro. Cármides - Lísis. Texto grego John Burnet. Tradução Carlos Alberto Nunes. 3. ed. Belém: Edufpa, 2015c. (Diálogos).

PLATÃo. Fedro. Primeiro Alcebiades - Segundo Alcebíades. Texto grego John Burnet. Tradução Carlos Alberto Nunes. 3. ed. Belém: Edufpa, 2015d. (Diálogos).

PLATÃo. Fedro.. Parmênides - Filebo. Tradução Carlos Alberto Nunes. Belém: Edufpa, 1974. (Diálogos, v. 8).

PlATÃo. Fedro.. Timeu, Crítias, O Segundo Alcebíades, Hipias Menor. 3. ed. Tradução Carlos Alberto Nunes. Belém: Edufpa, 2001b. (Diálogos).

SOFOCLES. As Traquínias. Tradução Flávio Ribeiro de Oliveira. Campinas: Editora Unicamp. 
2009.

SUSTEIN, Cass. R. Why Nudge? The Politics of Libertarian Paternalism.New Haven: Yale University Press. 2014.

VERBICARO, Loiane Prado. Judiicialização da Politica, Ativismo e Discricionariedade Judicial. Rio de Janeiro: Lumen Juris, 2017. 